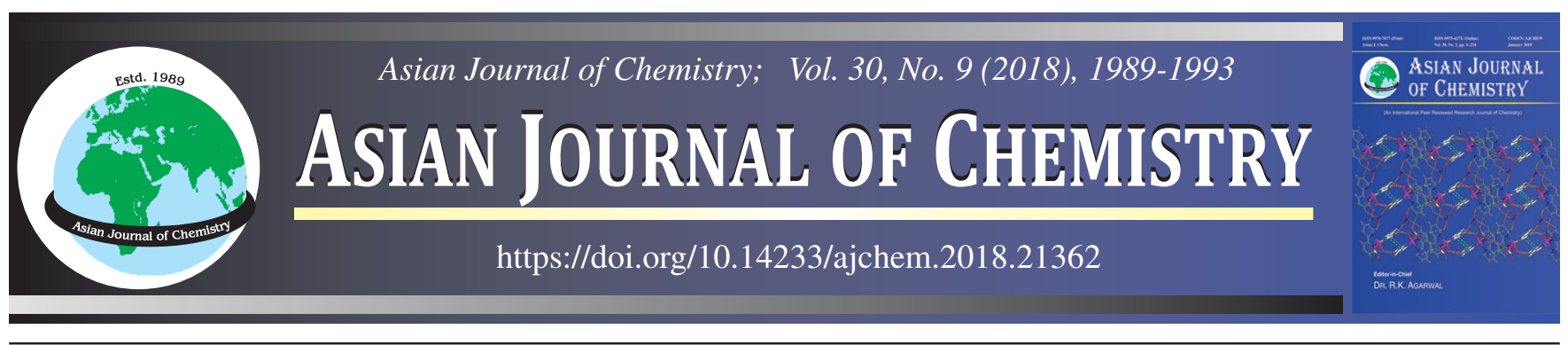

\title{
Synthesis and Characterization of Schiff Base Complexes of $o$-Vanillin and Anthranilic Acid and Their Biological Evaluation
}

Rajeev Pradhan ${ }^{1}$, Sumit Kumar Sinha ${ }^{2}$, Punam Verma $^{2}$, Sunny Kumar $^{2}$ and Shivadhar Sharma ${ }^{2, *}$

${ }^{1}$ Department of Chemistry, P.K. Roy Memorial College, Dhanbad-826 004, India

${ }^{2}$ Department of Chemistry, Magadh University, Bodh Gaya-824 234, India

*Corresponding author: Tel: +91 631 2220039; E-mail: sharma.shivadhar@gmail.com

Received: 2 April 2018;

Accepted: 10 May 2018;

Published online: 31 July 2018;

AJC-19007

Complexes of Schiff base derived from $o$-vanillin (2-hydroxy-3-methoxybenzaldehyde) and anthranilic acid (2-aminobenzoic acid) has been used for complexation with $\mathrm{Mn}(\mathrm{II}), \mathrm{Fe}(\mathrm{II})$ and $\mathrm{Co}(\mathrm{II})$. The complexes have been formulated as $\left[\mathrm{ML}_{2} \mathrm{X}_{2}\right]$ where $\mathrm{X}=$ pyridine or $\alpha-$ picoline on the basic of their microanalysis. Infrared spectral study has been made to confirm the coordination sites of the Schiff base. The magnetic susceptibility and electronic spectral study leads to tetragonally distorted octahedral symmetry $\left(\mathrm{T}_{4 \mathrm{~h}}\right)$ of complexes. Their biological evaluation with different strains of bacteria suggest that the complexes are more active than the ligand against both Gram-positive and Gram-negative bacteria.

Keywords: Magnetically dilute, Distorted octahedral, Escherichia colii, Bacillus subtilis, Schiff bases, Transition metal complexes. ᄂ _ - _ - _ - _ - - - - - - - - - - - - - - - - - - - - -

\section{INTRODUCTION}

The condensation of $o$-vanillin (2-hydroxy-3-methoxybenzaldehyde) with biologically active anthranilic acid (2aminobenzoic acid) leads to the formation of a stable Schiff base. It is an interesting and fascinating member of the family of Schiff bases containing two aromatic rings with - $\mathrm{OH}$ group at ortho position. The amino acids on condensation with an aldehyde group has shown conserved activity upon inactivation of the $-\mathrm{NH}_{2}$ group of the parent anthranilic acid [1-4]. Different types of Schiff base ligands and their transition metal complexes have been widely studied for biological [5-8], material [9-12] and industrial applications $[13,14]$. In the field of coordination chemistry the Schiff base ligand have received special attention as polyfunctional ligands in metal complexes which exhibit a variety of pharmaceutical activities like antimicrobial, antituberculosis, antitumoral and antioxidant agents [15-17]. Because of the biological relevance a large no. of transition metal complexes have been synthesized and explored as model system in bio-inorganic chemistry [18]. Generally Schiff base ligands act as chelating ligands and the biological activities of Schiff base ligands on coordination get enhanced [19-21]. From the fascinating biological activities of Schiff base comp- lexes, we made the study of synthesis, characterization and biological evaluation of some transition metal complexes with Schiff base ligand derived from $o$-vanillin and anthranilic acid i.e., $\mathrm{N}$-(2'-benzoic acid)-2-hydroxy-3-methoxy benzalidine (BHMBH).

\section{EXPERIMENTAL}

All the reagents used for present work of Anal-R grade, $o$-vanillin was procured from Aldrich was used without further purification. Anthranilic acid was prepared by Hoffmann bromamide method [22] that involves the oxidation of phthalimide with aquous sodium hypochloride followed by treatment with $\mathrm{HCl}$ as given in Scheme-I.

The Schiff base was prepared by the condensation of 0.01 M $(1.52 \mathrm{~g})$ of $o$-vanillin and $0.01 \mathrm{M}(1.37 \mathrm{~g})$ of anthranilic acid in ethanolic medium with $\mathrm{pH}$ in slightly acidic range (Scheme-II).

The metal complexes were prepared by refluxing $0.01 \mathrm{M}$ of metal salt of $\mathrm{Mn}$ (II), $\mathrm{Fe}$ (II) and $\mathrm{Co}$ (II) with $0.02 \mathrm{M}$ (5.42 g) of Schiff base BHMBH in ethanolic medium for 3-4 h. A little of sodium acetate was added to make the medium slightly alkaline followed by the addition of $0.02 \mathrm{M}$ of pyridine or $\alpha$-picoline slowly to the boiling solution. The solution was cooled

This is an open access journal, and articles are distributed under the terms of the Creative Commons Attribution-NonCommercial 4.0 International (CC BY-NC 4.0) License, which allows others to copy and redistribute the material in any medium or format, remix, transform, and build upon the material, as long as appropriate credit is given and the new creations are licensed under the identical terms. 


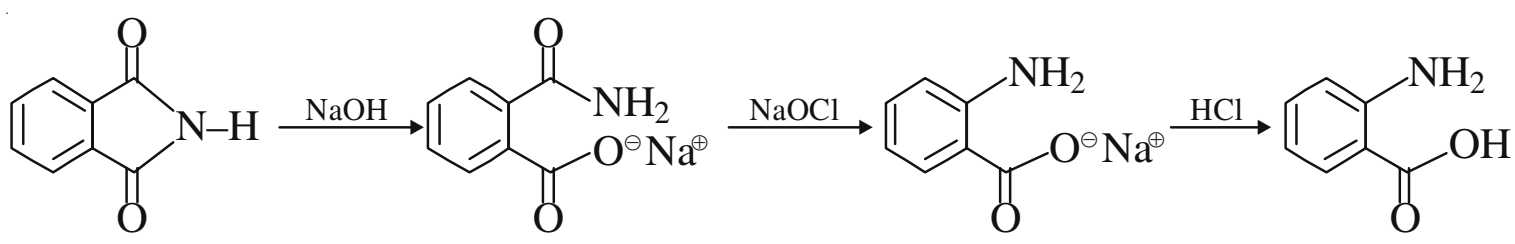

Scheme-I<smiles>COc1cccc(C=O)c1O</smiles>

Scheme-II

to room temperature and was stirred for 20 min where by the precipitate of complexes appeared which was filtered on suction and washed with ethanol. It was dried in an electric oven at $100{ }^{\circ} \mathrm{C}$. Their yield and melting points were recorded. The $\%$ of $\mathrm{C}, \mathrm{H}$ and $\mathrm{N}$ was determined Perkin-Elmer $2400 \mathrm{CHN}$ elemental analyzer and their molar conductivities were determined in $10^{-3} \mathrm{M}$ solution in DMF on conductivity meter CG857 Schott-Grate G-mbH. The IR spectra of the ligand and complexes were recorded on Shimadzu FTIR-8400 spectrophotometer using $\mathrm{KBr}$ disc. Their magnetic susceptibility was determined at room temperature using Gouy balance while their electronic spectra were recorded on Perkin-Elmer UV/ vis spectrophotometer Lambda in D.M.F. solution. The \% composition, molar conductivity and magnetic susceptibility have been given in Table-1.

\section{RESULTS AND DISCUSSION}

The molar conductivities values for all the complexes are around $15 \mathrm{ohm}^{-1} \mathrm{~cm}^{2} \mathrm{~mol}^{-1}$ which indicate their non-electrolytic nature [23-26]. On the basis of \% composition and molar conductivity values, complexes are formulated as $\left[\mathrm{ML}_{2} \mathrm{X}_{2}\right]$ where $\mathrm{L}=\mathrm{BHMBH}$ and $\mathrm{X}=$ pyridine or $\alpha$-picoline.

Infrared spectra: The important IR-bands of ligands and complexes have been assigned and interpreted. The free ligand absorbs strongly at $3540 \mathrm{~cm}^{-1}$ due to phenolic $-\mathrm{OH}$ group stretching vibration $[27,28]$. This band does not undergo any change in the IR-spectra of complexes showing its noninvolvement in coordination. This medium band appearing at $3000 \mathrm{~cm}^{-1}$ is assigned to new C-H of phenyl group [29]. The bands at 1610 and $1525 \mathrm{~cm}^{-1}$ taken in conjugation with new $\mathrm{C}-\mathrm{H}$ stretching band affords a ready means of recognition of aromatic ring in the ligand [30,31]. The medium band appearing at $2820 \mathrm{~cm}^{-1}$ in the spectra of free ligand is assigned to stretching vibration of $\mathrm{C}-\mathrm{H}$ bond of methyl group of the ligand [32]. The presence of methoxy group in the ligand is further substantiated by a medium band at $1160 \mathrm{~cm}^{-1}$ in the IR-spectra of free ligand due to $v(\mathrm{C}-\mathrm{O}-\mathrm{C})$ stretching vibration. This band also does not suffer any change after complexation which is indicative of its non-participation in coordination. The weak band at $2730 \mathrm{~cm}^{-1}$ may be assigned to $v(\mathrm{CH}=)$ moiety of the free ligand. The sharp band appearing at $1640 \mathrm{~cm}^{-1}$ is assigned to $v(\mathrm{CH}=\mathrm{N})$ (azomethine group) vibration which undergoes shift by $30-35 \mathrm{~cm}^{-1}$ in complexes [33,34]. This indicates the coordination of azomethine nitrogen to the metal ion in complexes. The band at $1720 \mathrm{~cm}^{-1}$ in the IR spectra of free ligand is indicative of the presence of aro- $\mathrm{COOH}$ group in the free ligand. In complexes this band gets split into two bands and appears at $1570-1560 \mathrm{~cm}^{-1}$ and $1410-1400 \mathrm{~cm}^{-1}$ due to antisymmetric and symmetric stretching of $v(\mathrm{C}-\mathrm{O})$ of

of acid group has occurred followed by its coordination through oxygen $[35,36]$. The separation between $v_{\text {assym }}$ and $v_{\text {sym }}$ of $-\mathrm{COO}^{-}$group is about $160 \mathrm{~cm}^{-1}$ which is indicative of monodentate coordination of the carboxylate ion $[37,38]$. The IRspectra of complexes $\mathbf{1}, \mathbf{3}$ and $\mathbf{5}$ display a new band at 760$750 \mathrm{~cm}^{-1}$ due to the coordination of pyridine through nitrogen and the complexes no. 2, 4 and $\mathbf{6}$ show the appearance of a new band at $810-800 \mathrm{~cm}^{-1}$ due to co-ordination of $\alpha$-picoline through nitrogen $[39,40]$. The new band appearing at 425410 and $510-500 \mathrm{~cm}^{-1}$ are safely assigned to $v(\mathrm{M}-\mathrm{O})$ and $v(\mathrm{M}-$ $\mathrm{N})$ stretching vibration further conform our above assertion of the coordination mode of the ligand [41].

TABLE-1

PERCENTAGE COMPOSITION, MOLAR CONDUCTANCE AND MAGNETIC MOMENT (FOUND/CALCULATED)

\begin{tabular}{llccccccc}
\hline \multicolumn{1}{c}{ Complexes } & \multicolumn{1}{c}{ Colour } & m.p. $\left({ }^{\circ} \mathrm{C}\right)$ & $\mathrm{M}$ & $\mathrm{C}$ & $\mathrm{H}$ & $\mathrm{N}$ & $\begin{array}{c}\lambda_{\mathrm{m}}\left(\mathrm{ohm}^{-1}\right. \\
\left.\mathrm{cm}^{2} \mathrm{~mol}^{-1}\right)\end{array}$ & $\mu_{\text {eff }}(\mathrm{B} . \mathrm{M})$. \\
\hline Schiff base $(\mathrm{BHMBH})$ & Light yellow & 192 & - & $66.68(66.42)$ & $4.43(4.40)$ & $5.00(5.17)$ & - \\
{$\left[\mathrm{MnL}_{2}(\text { py })_{2}\right]$} & Light orange & 278 & $7.12(7.28)$ & $63.72(63.58)$ & $4.48(4.77)$ & $7.33(7.42)$ & 15.30 & 5.86 \\
{$\left[\mathrm{MnL}_{2}(\alpha-\text { pico })_{2}\right]$} & Orange & 280 & $6.92(7.02)$ & $64.58(64.36)$ & $4.88(5.11)$ & $7.00(7.15)$ & 10.60 & 5.82 \\
{$\left[\mathrm{FeL}_{2}(\text { py })_{2}\right]$} & Green & 292 & $7.28(7.40)$ & $63.72(63.49)$ & $4.45(4.76)$ & $7.32(7.40)$ & 13.23 & 5.10 \\
{$\left[\mathrm{FeL}_{2}(\alpha-\text { pico })_{2}\right]$} & Light green & 298 & $7.00(7.14)$ & $64.46(64.28)$ & $4.96(5.10)$ & $6.95(7.14)$ & 14.45 & 5.12 \\
{$\left[\mathrm{CoL}_{2}(\text { py })_{2}\right]$} & Light pink & 310 & $7.52(7.77)$ & $63.46(63.24)$ & $4.51(4.74)$ & $7.16(7.38)$ & 11.51 & 4.80 \\
{$\left[\mathrm{CoL}_{2}(\alpha-\text {-pico })_{2}\right]$} & Light pink & 315 & $7.31(7.50)$ & $64.34(63.04)$ & $6.91(5.08)$ & $6.52(6.73)$ & 15.10 & 4.83 \\
\hline
\end{tabular}




\begin{tabular}{cccccc}
\hline \multicolumn{9}{c}{ TABLE-3 } \\
\hline Complexes & $\mathrm{Dq}\left(\mathrm{cm}^{-1}\right)$ & $\mathrm{B}\left(\mathrm{cm}^{-1}\right)$ & $\mathrm{C}\left(\mathrm{cm}^{-1}\right)$ & $\beta(\%)$ & $\mathrm{C} / \mathrm{B}$ \\
\hline$\left[\mathrm{Mn}(\mathrm{BHMBH})_{2}(\mathrm{py})_{2}\right]$ & 1034.47 & 862.06 & 3084.98 & 0.1136 & 3.579 \\
{$\left[\mathrm{Mn}(\mathrm{BHMBH})_{2}(\alpha-\text { pico })_{2}\right]$} & 1063.63 & 844.15 & 3029.89 & 0.137 & 3.589 \\
\hline
\end{tabular}

\section{Magnetic moment and electronic spectra}

Mn(II) complexes: The magnetic moment of Mn(II) complexes lies between 5.82-5.86 B.M. which is very close to the $\mu_{\mathrm{s}}$ value corresponding to five unpaired electrons. It shows that these complexes are spin free octahedral magnetically dilute [42]. The electronic spectra of Mn(II) complexes display three bands which has been given in Table-2 below with their assignments.

\section{TABLE-2}

\begin{tabular}{llll}
\hline \multirow{2}{*}{ Complexes } & \multicolumn{3}{c}{ Electronic spectral bands $\left(\mathrm{cm}^{-1}\right)$} \\
\cline { 2 - 4 } & \multicolumn{1}{c}{$v_{1}$} & $v_{2}$ & $v_{3}$ \\
\hline$\left[\mathrm{Mn}(\text { BHMBH })_{2}(\text { py })_{2}\right]$ & 20000 & 24000 & 30080 \\
{$\left[\mathrm{Mn}(\mathrm{BHMBH})_{2}(\alpha-\text { pico })_{2}\right]$} & 19500 & 23480 & 29500 \\
\hline Assignments: & & \\
$v_{1}:{ }^{6} \mathrm{~A}_{1 \mathrm{~g}} \longrightarrow{ }^{4} \mathrm{~T}_{\mathrm{gg}}\left({ }^{4} \mathrm{G}\right)=20000 \& 19500 \mathrm{~cm}^{-1}$ & \\
$\mathrm{v}_{2}:{ }^{6} \mathrm{~A}_{1 \mathrm{~g}} \longrightarrow{ }^{4} \mathrm{~T}_{2 \mathrm{~g}}\left({ }^{4} \mathrm{G}\right)=24000 \& 23480 \mathrm{~cm}^{-1}$ \\
$v_{3}:{ }^{6} \mathrm{~A}_{1 \mathrm{~g}} \longrightarrow{ }^{4} \mathrm{E}_{\mathrm{g}}\left({ }^{4} \mathrm{D}\right)=30080 \& 29500 \mathrm{~cm}^{-1}$
\end{tabular}

The low intensity of these bands may be attributed to the spin forbidden transition [43]. The values of different crystal field parameters have been derived using Tanabe-Sugano diagram and the values have been displayed in Table-3.

The value of C/B derived for Mn(II) complexes (3.579 and 3.589) is very close to the theoretical value 3.8 . The greater value of Dq for the second complex is due to the effect of the secondary ligand $\alpha$-picoline which is a better donor than the pyridine due to $+\mathrm{I}$ effect of $-\mathrm{CH}_{3}$ group at $\alpha$-position. The values are in good agreement with those reported for octahedral complexes of Mn(II) [44-46].

$\mathrm{Fe}$ (II) complexes: The magnetic moment of Fe(II) complexes are 5.10 and 5.12 B.M. The values are greater than expected for 4 unpaired electrons, $\mathrm{t}_{2 \mathrm{~g}}{ }^{4} \mathrm{eg}^{2}$ (4.898 B.M.) which may be due to the strong contribution from triply degenerate ground term, ${ }^{5} \mathrm{~T}_{2 \mathrm{~g}}$ in octahedral symmetry. Their electronic spectra display three bands which indicate the further splitting of both ground state ${ }^{5} \mathrm{~T}_{2 \mathrm{~g}}$ and excited state ${ }^{5} \mathrm{E}_{\mathrm{g}}$ under the influence of tetragonal distortion. The bands and their assignments have been given in Table- 4 .

\section{TABLE-4}

\begin{tabular}{cccc}
\hline \multirow{2}{*}{ Complexes } & \multicolumn{3}{c}{ Electronic spectral bands $\left(\mathrm{cm}^{-1}\right)$} \\
\cline { 2 - 4 } & $v_{1}$ & $v_{2}$ & $v_{3}$ \\
\hline$\left[\mathrm{Fe}(\mathrm{BHMBH})_{2}(\text { py })_{2}\right]$ & 8300 & 17400 & 20000 \\
{$\left[\mathrm{Fe}(\mathrm{BHMBH})_{2}(\alpha-\text { pico })_{2}\right]$} & 8700 & 18380 & 20100 \\
\hline Assignments: & & & \\
${ }^{5} \mathrm{E}_{\mathrm{g}} \longrightarrow{ }^{5} \mathrm{~B}_{2 \mathrm{~g}}\left(v_{1}\right) ;{ }^{5} \mathrm{E}_{\mathrm{g}} \longrightarrow{ }^{5} \mathrm{~A}_{1 \mathrm{~g}}\left(v_{2}\right) ;{ }^{5} \mathrm{E}_{\mathrm{g}} \longrightarrow{ }^{5} \mathrm{~B}_{2 \mathrm{~g}}\left(v_{3}\right)$ &
\end{tabular}

Various crystal field parameters have been derived from the electronic spectral bands and values have been displayed in Table-5.

The values obviously show that there is appreciable amount of distortion in octahedral symmetry of Fe(II) complexes.

\begin{tabular}{ccccc}
\hline \multicolumn{5}{c}{ TABLE-5 } \\
\hline Complexes & $\begin{array}{c}\mathrm{Dq}_{(\mathrm{xy})} \\
\left(\mathrm{cm}^{-1}\right)\end{array}$ & $\begin{array}{c}\mathrm{Dq}_{(\mathrm{z})} \\
\left(\mathrm{cm}^{-1}\right)\end{array}$ & $\begin{array}{c}\mathrm{D}_{\mathrm{s}} \\
\left(\mathrm{cm}^{-1}\right)\end{array}$ & $\begin{array}{c}\mathrm{D}_{\mathrm{t}} \\
\left(\mathrm{cm}^{-1}\right)\end{array}$ \\
\hline$\left[\mathrm{Fe}(\mathrm{BHMBH})_{2}(\text { py })_{2}\right]$ & 1170 & 5709 & 1557 & 2594 \\
{$\left[\mathrm{Fe}(\mathrm{BHMBH})_{2}(\alpha-\text { pico })_{2}\right]$} & 1140 & 5746 & 1488 & 2632 \\
\hline
\end{tabular}

Co(II) complexes: The magnetic moment of Co(II) complexes have been found 4.80 and 4.83 B.M. These values are in good agreement with the values reported for octahedral complexes of Co(II) $[47,48]$. Cobalt(II) complexes display three bands in their electronic spectra. The spectral band with their assignment have been displayed in Table-6.

\begin{tabular}{cccc}
\multicolumn{4}{c}{ TABLE-6 } \\
\hline \multirow{2}{*}{ Complexes } & \multicolumn{3}{c}{ Electronic spectral bands $\left(\mathrm{cm}^{-1}\right)$} \\
\cline { 2 - 4 } & $v_{1}$ & $v_{2}$ & $v_{3}$ \\
\hline$\left[\mathrm{Co}(\text { BHMBH })_{2}(\mathrm{py})_{2}\right]$ & 7200 & 15250 & 19300 \\
{$\left[\mathrm{Co}(\mathrm{BHMBH})_{2}(\alpha-\text { pico })_{2}\right]$} & 7300 & 15360 & 19450 \\
\hline Assignments: & & & \\
${ }^{4} \mathrm{E}_{1 \mathrm{~g}} \longrightarrow{ }^{2} \mathrm{~T}_{2 \mathrm{~g}}\left(v_{1}\right) ;{ }^{4} \mathrm{~T}_{1 \mathrm{~g}} \longrightarrow{ }^{4} \mathrm{~A}_{2 \mathrm{~g}}\left(\mathrm{v}_{2}\right) ;{ }^{4} \mathrm{~T}_{1 \mathrm{~g}} \longrightarrow{ }^{4} \mathrm{~T}_{\mathrm{lg}}(\mathrm{P})\left(\mathrm{v}_{3}\right)$
\end{tabular}

Various crystal field parameters have been derived by using reported equations [49] and the values have been shown in Table-7.

\begin{tabular}{lcccc}
\multicolumn{5}{c}{ TABLE-7 } \\
\hline \multicolumn{1}{c}{ Complexes } & $v_{2} / v_{1}$ & $\begin{array}{l}10 \mathrm{Dq} \\
\left(\mathrm{cm}^{-1}\right)\end{array}$ & $\mathrm{B}\left(\mathrm{cm}^{-1}\right)$ & $\beta(\%)$ \\
\hline$\left[\mathrm{Co}(\mathrm{BHMBH})_{2}(\mathrm{py})_{2}\right]$ & 2.12 & 10605 & 731.4 & 24.59 \\
{$\left[\mathrm{Co}(\mathrm{BHMBH})_{2}(\alpha-\text { pico })_{2}\right]$} & 2.104 & 11992 & 648.24 & 33.17 \\
\hline
\end{tabular}

Values of different crystal field parameters are in good agreement with the reported values for octahedral values for octahedral Co(II) complexes with slight distortion [50,51]. The tentative structure of the metal complexes may be given as:

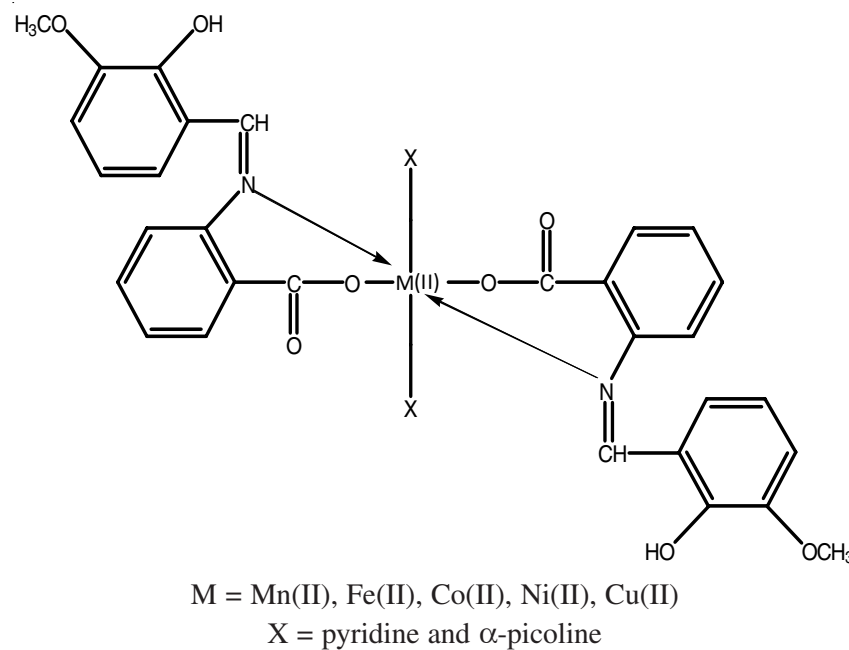

Biological evaluation: The ligand as well as complexes were screened for their in vitro antibacterial activity against 


\begin{tabular}{|c|c|c|c|c|c|c|c|c|c|c|c|c|c|c|c|c|}
\hline \multirow[b]{4}{*}{ Concentration } & \multicolumn{14}{|c|}{$\begin{array}{l}\text { TABLE- } 8 \\
\text { GAND AND ITS COMPLEXES-DIAMETER OF } \\
\text { m) AND ACTIVITY INDEX }(\%)\end{array}$} & & \\
\hline & \multicolumn{8}{|c|}{ Gram-positive bacteria } & \multicolumn{8}{|c|}{ Gram-negative bacteria } \\
\hline & \multicolumn{2}{|c|}{$\begin{array}{c}\text { Inhibition } \\
\text { zone }\end{array}$} & \multicolumn{2}{|c|}{ Activity zone } & \multicolumn{2}{|c|}{$\begin{array}{c}\text { Inhibition } \\
\text { zone }\end{array}$} & \multicolumn{2}{|c|}{ Activity zone } & \multicolumn{2}{|c|}{$\begin{array}{c}\text { Inhibition } \\
\text { zone }\end{array}$} & \multicolumn{2}{|c|}{ Activity zone } & \multicolumn{2}{|c|}{$\begin{array}{l}\text { Inhibition } \\
\text { zone }\end{array}$} & \multicolumn{2}{|c|}{ Activity zone } \\
\hline & 50 & 100 & 50 & 100 & 50 & 100 & 50 & 100 & 50 & 100 & 50 & 100 & 50 & 100 & 50 & 100 \\
\hline Schiff base (BHMBH) & 12 & 15 & 66.66 & 68.18 & 11 & 16 & 64.70 & 66.66 & 12 & 19 & 66.66 & 67.85 & 11 & 15 & 68.75 & 68.18 \\
\hline$\left[\mathrm{MnL}_{2}(\mathrm{py})_{2}\right]$ & 17 & 21 & 94.44 & 95.45 & 16 & 23 & 94.11 & 95.83 & 17 & 27 & 94.44 & 96.42 & 15 & 21 & 93.75 & 95.45 \\
\hline$\left[\mathrm{MnL}_{2}(\alpha-\text { pico })_{2}\right]$ & 17 & 21 & 94.44 & 95.45 & 16 & 23 & 94.11 & 95.83 & 17 & 27 & 94.44 & 96.42 & 15 & 21 & 93.75 & 95.45 \\
\hline$\left[\mathrm{FeL}_{2}(\mathrm{py})_{2}\right]$ & 16 & 19 & 88.88 & 86.36 & 15 & 21 & 88.23 & 87.50 & 16 & 24 & 88.88 & 85.71 & 14 & 19 & 87.50 & 86.36 \\
\hline$\left[\mathrm{FeL}_{2}(\alpha-\text { pico })_{2}\right]$ & 16 & 19 & 88.88 & 86.36 & 15 & 21 & 88.23 & 87.50 & 16 & 24 & 88.88 & 85.71 & 14 & 19 & 87.50 & 86.36 \\
\hline$\left[\mathrm{CoL}_{2}(\mathrm{py})_{2}\right]$ & 15 & 18 & 83.33 & 81.81 & 14 & 20 & 82.35 & 83.33 & 15 & 23 & 83.33 & 82.14 & 13 & 18 & 81.25 & 81.81 \\
\hline$\left[\mathrm{CoL}_{2}(\alpha-\text { pico })_{2}\right]$ & 15 & 18 & 83.33 & 81.81 & 14 & 20 & 82.35 & 83.33 & 15 & 23 & 83.33 & 82.14 & 13 & 18 & 81.25 & 81.81 \\
\hline Streptomycin & 18 & 22 & 100 & 100 & 17 & 24 & 100 & 100 & 18 & 28 & 100 & 100 & 16 & 22 & 100 & 100 \\
\hline
\end{tabular}

TABLE-9

ANTIFUNGAL SCREENING OF LIGAND AND ITS COMPLEXES-DIAMETER OF INHIBITION ZONE (mm) and ACTIVITY INDEX (\%)

\begin{tabular}{lcc|cc|cccc}
\hline & \multicolumn{4}{c|}{ Asepergillus flavu } & \multicolumn{4}{c}{ Fusariumoxy } \\
\cline { 2 - 8 } & \multicolumn{2}{c|}{ Inhibition zone } & \multicolumn{2}{c|}{ Activity zone } & \multicolumn{2}{c}{ Inhibition zone } & \multicolumn{2}{c}{ Activity zone } \\
\hline Concentration & 50 & 100 & 50 & 100 & 50 & 100 & 50 \\
\hline Schiff base $(\mathrm{BHMBH})$ & 14 & 19 & 70.00 & 67.85 & 13 & 19 & 68.42 \\
{$\left[\mathrm{MnL}_{2}(\text { py })_{2}\right]$} & 19 & 27 & 95.00 & 96.42 & 18 & 27 & 94.73 \\
{$\left[\mathrm{MnL}_{2}(\alpha-\text { pico })_{2}\right]$} & 19 & 27 & 95.00 & 96.42 & 18 & 27 & 94.73 \\
{$\left[\mathrm{FeL}_{2}(\text { py })_{2}\right]$} & 17 & 24 & 85.00 & 85.71 & 16 & 24 & 84.21 \\
{$\left[\mathrm{FeL}_{2}(\alpha-\text { pico })_{2}\right]$} & 17 & 24 & 85.00 & 85.71 & 16 & 24 & 84.21 \\
{$\left[\mathrm{CoL}_{2}(\text { py })_{2}\right]$} & 16 & 23 & 80.00 & 82.14 & 15 & 23 & 78.94 \\
{$\left[\mathrm{CoL}_{2}(\alpha-\text { pico })_{2}\right]$} & 16 & 23 & 80.00 & 82.14 & 15 & 23 & 78.71 \\
$\mathrm{Clotrimazole}$ & 20 & 28 & 100 & 100 & 19 & 28 & 82.14 \\
\end{tabular}

Gram-positive bacteria Bacillus subtilis, Staphylococcus aureus and Gram-negative bacteria Escherichia coli and Klebsilla pneumonia by disc diffusion method using nutrient Agar as medium and streptomycin as control. The in vitro antifungal activities of the ligand and its metal complexes have been tested against the fungi Asepergillus flavu and Fusariumoxy by well diffusion method on potato dextrose agar as the medium and clotrimazole as control. The compounds were dissolved in DMSO and solution of different concentration like $50 \mathrm{ppm}$ and $100 \mathrm{ppm}$ were prepared separately. The well mode on agar medium was inoculated with microorganism. The well was filled with the test solution using a micro pipette and the plate was incubated $24 \mathrm{~h}$ for bacteria at $35^{\circ} \mathrm{C}$ and $72 \mathrm{~h}$ for fungi at $30^{\circ} \mathrm{C}$. During this period the test solution got diffused and the growth of inoculated microorganism was effected. The inhibition zone was developed at which the concentration was noted down. All the determinations were performed thrice and activity index of compounds was determined using the expression: Inhibition zone by test compound

Activity index $(\%)=\frac{(\text { diameter in } \mathrm{mm})}{\text { Inhibition zone by control compound }} \times 100$ (diameter in $\mathrm{mm}$ )

The results have been displayed in Tables 8 and 9. It is obvious from the results that the ligand and its metal complexes show positive activity towards Gram-positive and Gramnegative bacteria and also to the fungi. It is also clear that the biological activity of the ligand gets enhanced appreciably in complexes. The activity of the ligand may be attributed to azomethine linkage in it. The increased activity of the metal complexes can be ascribed to the increase in lipophilic nature of complexes due to chelation [52]. All Mn(II) complexes show the highest activity which may be due to its toxic nature [53].

\section{Conclusion}

On the basis of forgoing study of the transition metal complexes it may be concluded that the ligand acts as mono anionic bidentate coordinating through azomethine nitrogen and deprotonated carboxylic acid oxygen forming a six membered chelate. The complexes are octahedral with slightly tetragonal distortion. The ligand as well as its complexes are active against Gram-positive and Gram-negative bacteria and also against both the fungi. The biological activity of ligand gets enhanced after complexation with transition metal ions.

\section{CONFLICT OF INTEREST}

The authors declare that there is no conflict of interests regarding the publication of this article.

\section{REFERENCES}

1. A. Zubrys and C.O. Siebenmann, Can. J. Chem., 33, 11 (1955); https://doi.org/10.1139/v55-003.

2. R. Maccari, R. Ottana and M.G. Vigorita, Bioorg. Med. Chem. Lett., 15, 2509 (2005); https://doi.org/10.1016/j.bmcl.2005.03.065.

3. B. Villemagne, C. Crauste, M. Flipo, A.R. Baulard, B. Deprez and N. Willand, Eur. J. Med. Chem., 51, 1 (2012); https://doi.org/10.1016/j.ejmech.2012.02.033.

4. M.A. Bhat and M.A. Al-Omar, Med. Chem. Res., 22, 4522 (2013); https://doi.org/10.1007/s00044-012-0458-3.

5. A.M. Abu-Dief and I.M.A. Mohamed, Beni-Suef Univ. J. Basic Appl. Sci., 4, 119 (2015); https://doi.org/10.1016/j.bjbas.2015.05.004. 
6. W. Al Zoubi, Int. J. Org. Chem., 3, 73 (2013); https://doi.org/10.4236/ijoc.2013.33A008.

7. C.M. da Silva, D.L. da Silva, L.V. Modolo, R.B. Alvesa, M.A. de Resende, C.V.B. Martins and Â. Fátima, J. Adv. Res., 2, 1 (2011); https://doi.org/10.1016/j.jare.2010.05.004.

8. G. Levy and T. Tsuchiya, N. Engl. J. Med., 287, 430 (1972); https://doi.org/10.1056/NEJM197208312870903.

9. G. Gran, Analyst, 77, 661 (1952); https://doi.org/10.1039/an9527700661.

10. D.B. Watlaufer, S.K. Malik, L. Stoller and R.L. Coffin, J. Am. Chem. Soc., 86, 508 (1964); https://doi.org/10.1021/ja01057a045.

11. G. Gran, Anal. Chim. Acta, 206, 111 (1988); https://doi.org/10.1016/S0003-2670(00)80835-1.

12. R.S. Rao and G.N. Rao, Computer Applications in Chemistry, Himalaya Publishing House, Mumbai, India, p. 302 (2005).

13. V.G. Kumari, M. Ramanaiah and B.B.V. Sailaja, Chem. Spec. Bioavail., 27, 121 (2015); https://doi.org/10.1080/09542299.2015.1087159.

14. C.N. Rao, M. Ramanaiah and B.B.V. Sailaja, Bull. Chem. Soc. Ethiop., 30, 71 (2016); https://doi.org/10.4314/bcse.v30i1.6.

15. R. Maccari, R. Ottanà, B. Bottari, E. Rotondo and M.G. Vigorita, Bioorg. Med. Chem. Lett., 14, 5731 (2004); https://doi.org/10.1016/j.bmcl.2004.09.052.

16. M.L. Ferreira, R.S.B. Gonçalves, L.N.F. Cardoso, C.R. Kaiser, A.L.P. Candéa, M.G.M.O. Henriques, M.C.S. Lourenço, F.A.F.M. Bezerra and M.V.N. de Souza, Sci. World J., 10, 1347 (2010); https://doi.org/10.1100/tsw.2010.124.

17. P. Krishnamoorthy, P. Sathyadevi, A.H. Cowley, R.R. Butorac and N. Dharmaraj, Eur. J. Med. Chem., 46, 3376 (2011); https://doi.org/10.1016/j.ejmech.2011.05.001.

18. M. Balakrishna, G.S. Rao, M. Ramanaiah, G.N. Rao and B. Ramaraju, Res. J. Pharm. Biol. Chem. Sci., 6, 1430 (2015)

19. P. Bindu, M.R.P. Kurup and T.R. Satyakeerty, Polyhedron, 18, 321 (1998); https://doi.org/10.1016/S0277-5387(98)00166-1.

20. R.V. Singh, N. Fahmi and M.K. Biyala, J. Iran. Chem. Soc., 2, 40 (2005); https://doi.org/10.1007/BF03245778.

21. D.K.A. Kumar, A.P. Sangamesh and S.B. Prema, Int. J. Electrochem. Sci., 4, 717 (2009).

22. I.L. Finar, Organic Chemistry, The English Language Book Society and Longmann Group Limited, London, edn 6, vol. 1, pp. $764-765$ (1982).

23. J.T. Makode and A.S. Aswar, Indian J. Chem., 43A, 2120 (2004).

24. K. Siddappa, P.C. Reddy, M. Kote, T. Reddy, M. Tambe and M. Mitra, Asian J. Chem., 23, 4511 (2011).

25. P. Kumari, S. Prakash and D. Prakash, J. Indian Chem. Soc., 89, 19 (2012).

26. R. Rani, R. Ranjan, N.C. Bhattacharzee, S. Sharma and F. Suraiya, J. Indian Chem. Soc., 90, 331 (2013).

27. R. Prabhakaran, V. Krishnan, A. Geetha, H. Bertagnolli and K. Natarajan, Inorg. Chim. Acta, 359, 1114 (2006); https://doi.org/10.1016/j.ica.2005.11.028.
28. S. Manivannan, A. Manimaran, S. Arunachalam, C. Jaibalkrishnan and V. Chinnusamy, J. Indian Chem. Soc., 85, 988 (2008).

29. S. Mallik, N. Kumari and D.K. Sharma, J. Indian Chem. Soc., 87, 539 (2010)

30. B.B. Mahapatra and N. Patel, J. Indian Chem. Soc., 86, 518 (2009).

31. A. Joseph, B. Joseph and B. Narayana, J. Indian Chem. Soc., 85, 479 (2008).

32. L.K. Mishra and B.K. Keshri, Indian J. Chem., 28A, 883 (1981).

33. A. Karim, R. Rani, R. Ranjan, U. Kumar, V. Kumar and S. Sharma, Asian J. Chem., 29, 626 (2017); https://doi.org/10.14233/ajchem.2017.20286.

34. J. Devi and M. Yadav, Asian J. Chem., 29, 551 (2017); https://doi.org/10.14233/ajchem.2017.20236.

35. K. Nakamoto, Infrared Spectra of Inorganic and Coordination Compounds, John Wiley \& Sons, Inc., New York, pp. 198-199 (1963).

36. R.N. Pandey and K. Sahi, Asian J. Chem., 23, 4508 (2011).

37. K.R.N. Bhowimik, A.K. De and R.N.D. Purkayastha, J. Indian Chem. Soc., 89, 177 (2012).

38. C.T. Yang, M. VetricheIvan, X. Yang, B. Moubaraki, K.S. Murry and J.J. Vittal, J. Chem. Soc., Dalton Trans., 113 (2014); https://doi.org/10.1039/B310262A.

39. M.K. Singh, A.D.R. Laskar and B. Paul, J. Indian Chem. Soc., 85, 485 (2008)

40. S. Chandra, D. Jain, A. Sarkar and Anupama, J. Indian Chem. Soc., 86, 220 (2009).

41. N. Raman, J. Indian Chem. Soc., 85, 1082 (2008).

42. B.C. Guha, Proc. R. Soc. Lond. A Math. Phys. Sci., 206, 353 (1951); https://doi.org/10.1098/rspa.1951.0075.

43. I.S. Ahuja, Indian J. Chem., 22A, 262 (1983).

44. V.P. Singh, S. Singh and A. Katiyar, J. Enzym. Inhib. Med. Chem., 24, 577 (2009); https://doi.org/10.1080/14756360802318662.

45. T.T. Al-Nahary, J. Saudi Chem. Soc., 13, 253 (2009); https://doi.org/10.1016/j.jscs.2009.10.004.

46. E. Soleimani, J. Chin. Chem. Soc., 57, 653 (2010); https://doi.org/10.1002/jccs.201000091.

47. A.K. Singh, S.P. Sinha, V. Kumar, S.S. Rai and S. Sharma, Asian J. Chem., 23, 4347 (2011)

48. B.K. Rai and R. Kumari, Asian J. Chem., 23, 4625 (2011).

49. A.B.P. Lever, Inorganic Electronic Spectroscopy, Elsevier, Amsterdam, edn 2, p. 818 (1984).

50. B.K. Rai, J. Indian Chem. Soc., 90, 105 (2013).

51. K. Anbalagan and A.S. Ganesh Raja, J. Indian Chem. Soc., 90, 133 (2013).

52. N. Soltani, M. Behpour, S.M. Ghoreishi and H. Naeimi, Corros. Sci., 52, 1351 (2010); https://doi.org/10.1016/j.corsci.2009.11.045.

53. M. Selvaganapathy and N. Raman, J. Chem. Biol. Ther., 1, 108 (2016); https://doi.org/10.4172/2572-0406.1000108. 